\title{
12
}

\section{South Saami Children's Choir: A Successful Project, Despite the Obstacles}

\author{
Åsa Virdi Kroik
}

Røyrvik is a community situated in the southern part of Saepmie, on the Norwegian side, in Nord-Trøndelag, with Jämtland District in Sweden to its east. The community is inhabited by approximately 500 persons, of which 10-20 per cent are believed to be Saami. From a South Saami perspective, this area is considered to be among the most culturally strong and significant areas, as many Saami have their origin here. Some important and powerful persons in South Saami history also have their origins here. One example of such a person was Ella Holm Bull (19292006), a preserver of the Saami language who produced a considerable amount of educational literature and music in South Saami, and was an initiator of, and for a couple of years the principal of, the Saami school Åarjel saemiej skuvle (Hermanstrand 2009: 345). The geographical area of the Røyrvik community was colonised rather late in Norweigan history, with the earliest settlers coming as late as 1806.

Colonisation, and damming and mining in the area from 1950-2000, dramatically changed the daily life of the reindeer-herding Saami people in the Røyrvik area. Reindeer herding became markedly disturbed, for instance, by the damming of Lake Namsvatn, where a whole village was drowned and had to be rebuilt on the new shore higher up (Jürgensen, et 
al. 2013: 93-94). Among the Saami many lakes are believed to be sacred, and this lake's name, Namsvatn, implies that this might be the case. 'Vatn' is 'water' in Swedish/Norwegian and 'nam' may refer to 'name' in Saami (nomme or nimme), possibly associated with the idea that some things are too sacred to speak about or name (see Kroik 2005a). Place names surrounding the lake also indicate that it was sacred (Kroik 2005a). These things are rarely talked about in public among the Saami themselves and can only be studied with difficulty in contemporary South Saami society. Just as with many other Indigenous peoples, Saami are often described as a people of few words (Dahl 1940: 192; Jernsletten 2000: 7; Devy 2006: 55; Svestad 2013: 57). The Saami traditional reindeer-herding economy is vital in today's society and it is the largest local primary economy-an economic power that cannot be neglected by the community leaders.

Because of this and other factors, the conflicts between reindeer herders and settlers that increased during the 1980s were dealt with in a historic theatre project called Bru mellom kulturer [Bridges between cultures]. The project involved an impressive proportion of the total inhabitants of the Røyrvik community, and had a calming effect on the increasingly heated emotional climate in the community (Jürgensen, et al. 2013). There were moments of insight and regret during the work period, which were described by the participants as very powerful.

There have been, and still are, strong ties between the Saami on the Norwegian and Swedish sides. The national border was delineated in 1751 and cleaved a coherent traditional Saami area in two. However, it never completely divided the Saami people, who remained tied to each other by intermarriage, genealogy, culture, economy and a common history (Kroik 2007: 29-30). Still, the Saami have been culturally affected by the nation state and domination culture in each country, something that is obvious, for instance, by their first language, which is often, but not always, that of the national majority.

For three years, I lived and worked in Røyrvik. As a coordinator for local Saami language and culture, I had the challenge of recruiting participants to different language and cultural projects out of the small population of the Saami in the area.

Of all the education I have received in my life, there is one thing I learned that I've had no substantial use for at all, and that is my education in music. For more than two years I learned music theory, spending hours 
and hours practising scales and etudes on guitar and piano. To my mother's despair, who was convinced that I had no singing voice, I not only practised my singing exercises at home, but I even asked the preacher in my home village if I could sing in the chapel. Anyone who knows how socially unacceptable it is for a Saami in the Nordic countries to make such a request, and thereby state that you think you have a competence worth showing, will understand how motivated I was and how much I must have enjoyed singing and performing. Well, as I said, once my education in music was complete, I never used my skills again in my working life, apart from once turning a page for a pianist holding a concert, while I was working as a verger in a church, as I was the only person who could read notes apart from the pianist.

In my work in Røyrvik, my ambition was that every generation should somehow benefit from the project. Most of the Saami children went to the boarding school in a larger village, Snåsa, 140 kilometres from Røyrvik, a community that promotes itself as being the South Saami capital. These children came to Røyrvik only on weekends and holidays. Luckily for me, there was one Saami family with four girls permanently staying in Røyrvik. And even luckier was that the youngest twins in this family were the same age as my daughter, and the oldest of the four girls just loved singing and performing. When I contacted the family, the oldest girl immediately agreed to participate, singing with me as her accompanist in the chapel at the midsummer festival.

Ankarede is a very important place-particularly for the South Saami. Nobody lives there permanently, but in summertime a café opens there and some huts are rented to tourists. The area is divided in two, with a Saami side where traditional gåtieh (Saami buildings) are located and Scandinavian summer houses are raised on the other side for the nonSaami population. All of them are owned privately by individual families. The café is situated opposite the church close to the parking place. It is not known when the first chapel was raised, but the current chapel was built in 1895 . The place has been a traditional meeting place at certain times of the year for the Saami reindeer herders, and the chapel was situated there so the Christian church could proselytise the Saami. Today, Saami from everywhere, as well as locals celebrate midsummer there. The oldest of the four sisters, Emma, and I performed in the chapel during the service. Emma gave a great performance, and it was very much appreciated to hear and see Ella Holm Bull's granddaughter singing songs in Saami that Ella had written. 
I realised that even if Emma was the most experienced and extroverted, the other girls were also very motivated. So, I started practising with all of them together with my own daughter, Jenny, who was six years old. As the girls lived on my way between home and work, it was easy for me to stop, and have a session, or just talk over a cup of coffee. The girls got along really well and even if we did practise some singing there was a lot of pauses where the youngest girls played with the dog or just had fun. That was also a good time for me to practise with the two eldest girls.

The sessions weren't very well planned from my side, and the girls also had a lot of other things to do, so the two oldest girls gave up after some time. To my surprise, the twins wanted to continue. We gathered some other Saami children from the nearby villages and spent one day practising in the village of Jorm, on the Swedish side, at the local hotel. That day was very joyful, and the children not only played with and teased each other, but we actually did some singing and joiking — traditional Saami singing-as well. We also gave a general rehearsal concert for some of the guests. I was very happy that the couple who ran the place let us use their hotel. They also had horses, which were fun for us to meet in the pauses. This was a rehearsal, preparing us for a concert in a retirement home in Røyrvik. The funny thing was that when we came there and sang our songs, the girls' uncle was there, visiting an elderly person. I had, of course, not had time to advertise the concert (my planning skills were, as I said, somewhat insufficient) so it was only by luck that he was there and had the opportunity to listen to the performance. I think his surprise was a happy one. After performing, we felt invigorated, so we gave an improvised bonus concert at the community house (Figure 8).

Even though I loved working with the girls, there were many obstacles. Lack of time was one, and lack of my ability to plan was another. I constantly had a bad conscience for not working with the girls as much as they were worth. I had some complaints about the lack of discipline and, yes, I was not focusing at all on discipline, but on fun. I didn't care if the girls were playing and singing at the same time-I just wanted them to use Saami words and see the Saami language and joik as something positive. The performances were only organised to motivate them, and maybe to make other people happy as well. None of us asked to be recorded or broadcast on radio, but rumours spread about our work and resulted in the radio station contacting us and recording us anyway. I don't know if the children learned any Saami at all. Except for the first performance in Ankarede, we did not promote ourselves any more, but people asked us to come and perform. There was definitely a need that we met. 


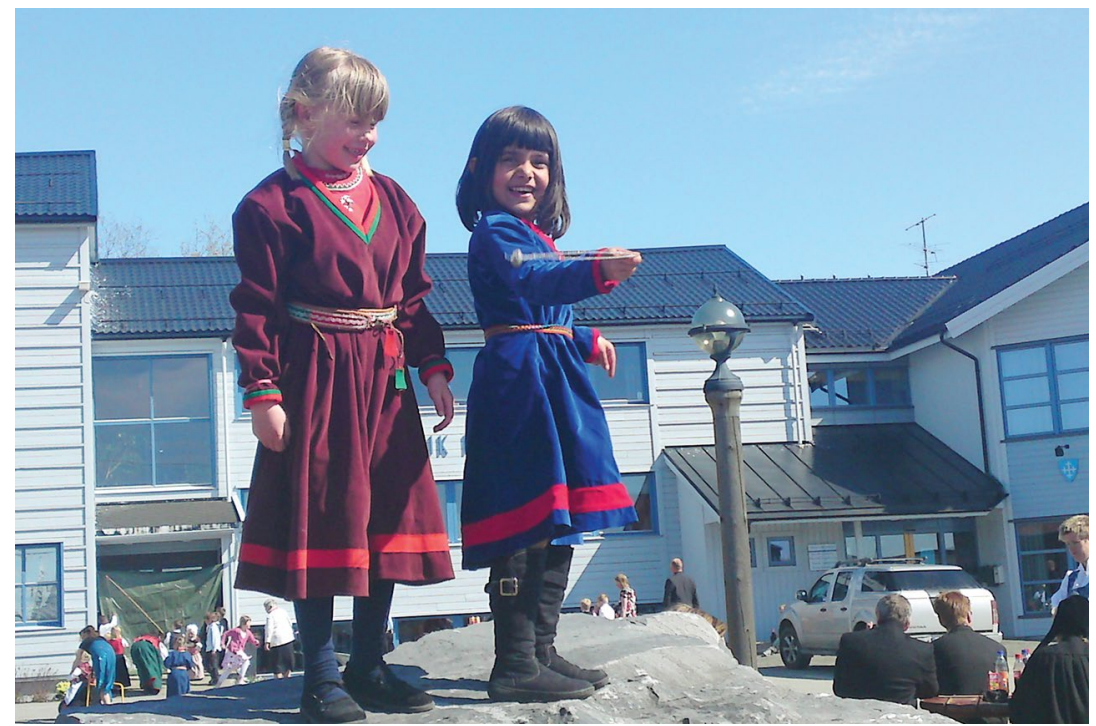

Figure 8. Maria Rustad (left) and Jenny Virdi Kroik wearing traditional South Saami clothes. Tin embroidery is used for decoration on the belt. They are playing outside after the concert.

Source. Photographed by Åsa Virdi Kroik, Röyrvik (Nord tröndelag, Norway), c. June 2010. Used with permission.

What made me most happy was when one of the twins said that before they started, they didn't know the Saami children from the other villages nearby, but after participating in our activities they all knew each other well. They now meet from time to time and they know that they are Saami. Hopefully, they also know some joik and songs. I think they do, because when they met in the school at Snåsa a few years later, they were able to perform a joik together without any preparation.

\section{References}

Dahl, Georg. 1940. Två år som Indian i Colombias Urskogar [Two Years as an Indian in the Virgin Forests of Columbia]. Stockholm: Natur och Kultur.

Devy, Ganesh N. 2006. A Nomad Called Thief: Reflections of Adivasi Silence. New Delhi: Orient Blackswan.

Hermanstrand, Håkon. 2009. Røyrvik - Samene i Østre Namdal [Røyrvik - The Saami of East Namdal]. Røyrvik: Røyrvik kommune. 
Jernsletten, Jorunn. 2000. Dovlede Jirreden. Kontekstuell Verdimidling i et Sørsamisk Miljø [With the Past Into the Future. Context-based Value Transmittance in a South Saami Environment]. Tromsø: Universitetet i Tromsø.

Johnsen, Tore and Line M. Skum (eds). 2013. Erkjenne Fortid - Forme Framtid. Innspill til Krikelig Forsoningsarbeid i Sápmi [Recognise the Past - Shape the Future]. Stamsund: Orkana forlag.

Jürgensen, Einmo, Ada Svestad, Anne-Bjørg Evensen and Fiskum Berit. 2013. 'Teater som Verktøy i en Forsonende Prosess - Røyrvik Kommune fra 2000 og in i Fremtiden' [Theatre as a Tool in the Process of Reconciliation - Røyrvik Municipality From the Year 2000 and Into the Future]. In Erkjenne FortidForme Framtid. Innspill til Krikelig Forsoningsarbeid i Sápmi [Recognise the Past - Shape the Future], edited by Tore Johnsen and Line M. Skum, 93-107. Stamsund: Orkana forlag.

Kroik, Åsa V. 2005a. 'Namsvatn - Heligt Vatten Med Samiskt Namn' [Namsvatn - Sacred Water Named in Saami]. In Där Renflocken Drar Förbi [Where the Flock of Reindeer Passes], edited by Åsa V. Kroik, 66-73. Göteborg: Boska Förningen för bevarande av samisk kultur och folkmedicin.

Kroik Åsa V. (ed.). 2005b. Där Renflocken Drar Förbi [Where the Flock of Reindeer Passes]. Göteborg: Boska - Förningen för bevarande av samisk kultur och folkmedicin.

Kroik, Åsa Virdi. 2007. Hellre Mista Sitt Huvud än Lämna Sin Trumma [Rather Lose Your Head Than Leave Your Drum]. Hönö : Boska - föreningen för bevarandet av samisk kultur och folkmedicin.

Svestad, Anne-Bjørn E. 2013. Kulturminnebasert Verdiskaping - En Balansegang Mellom Ulike Intresser [Valuemaking Based in Cultural Mememories A Balance Between Differing Interests]. Trondheim: NTNU Norge teknisknaturvitenskaplige universitet. 
This text is taken from Indigenous Efflorescence: Beyond Revitalisation in Sapmi and Ainu Mosir, edited by Gerald Roche, Hiroshi Maruyama and Åsa Virdi Kroik, published 2018 by ANU Press, The Australian National University, Canberra, Australia.

doi.org/10.22459/IE.2018.12 